\title{
PENERAPAN PENDIDIKAN CERDAS BERKARAKTER DI MERAUKE (PERSPEKTIF KOMUNIKASI)
}

\author{
Ririt Yuniar \\ Fakultas IImu Komunikasi Universitas Pancasila \\ e-mail: rirityuniar@gmail.com \\ Rafika Puspitasari \\ Fakultas IImu Komunikasi Universitas Pancasila \\ e-mail: rafikapspt@gmail.com
}

\begin{abstract}
Education is the most important factor in order to increase the people's intelligence which is in accordance to the value of Pancasila, the basis of the Indonesian state, since character is the most important aspect in the nation's social life. Unfortunately, some parts (provinces) of Indonesia especially Merauke for the example - doesn't receive quite education for the character-building and enrichment to happen. This is fatal enough considering good character equals good standards of living. This research aims to persuade all layers of society and the local government in order to initiate a great character-building education in Merauke, meanwhile it is also testing how much the government's intelligent character policy has been applied in Merauke. This research uses a qualitative and descriptive approach, along with the constructivist's paradigm. The results of the research have been concluded that the Merauke is still experiencing a crisis character in terms of education. It's about time that the local government, all layers of society, and all of those who are involved to assist one another to resolve the issue of character-building education especially in Merauke. The conclusion of the research is that a strategic communication and social interactions in the form of awareness-raising can be the bridge for implementing a great character-building policy in Merauke.
\end{abstract}

Keywords: education, character, standard of living, Merauke

\begin{abstract}
Abstrak
Pendidikan merupakan komponen terpenting guna mencerdaskan kehidupan bangsa yang harus disertai dengan pembinaan karakter berdasarkan nilai-nilai Pancasila. Karakter merupakan komponen dasar dalam kehidupan sosial berbangsa dan bernegara. Sayangnya, dibeberapa daerah bagian Indonesia khususnya Merauke persoalan mengenai pembangunan karakter masih terabaikan dan dapat berakibat fatal dalam peningkatan taraf hidup masyarakat Merauke. Penelitian ini bertujuan untuk mengajak seluruh golongan untuk berpartisipasi dalam
\end{abstract}


mewujudkan pendidikan cerdas berkarakter serta mengetahui bagaimana implementasi kebijakan cerdas berkarakter di bagian timur Merauke. Penelitian ini menggunakan pendekatan deskriptif kualitatif dan paradigma konstruktivis. Hasil penelitian ini adalah Merauke masih mengalami krisis secara karakter dari kacamata pendidikan. Sudah selayaknya jika seluruh lapisan elemen masyarakat, pemerintah, serta semua partisipator dapat bersama-sama saling membantu satu sama lain menyelesaikan persoalan pendidikan karakter khususnya di Merauke. Komunikasi yang strategis dapat menjadi jembatan bagi implementasi kebijakan cerdas berkarakter yang dicanangkan oleh pemerintah pusat dan bagi seluruh tenaga pengajar yang memberikan pendidikan karakter bagi pelajar Merauke.

Kata Kunci: pendidikan, karakter, taraf hidup, Merauke

\section{PENDAHULUAN}

Melihat cita-cita bangsa yang termaktub dalam pembukaan Undang-Undang Dasar 1945 alinea ke-empat yang menyatakan bahwa seluruh rakyat Indonesia berhak mendapatkan kehidupan yang layak dan sejahtera untuk mencapai kemakmuran serta mencerdaskan rakyat dari keterbelakangan pendidikan. Sejak merdeka pada tahun 1945, Indonesia diyakini sudah gencar untuk melakukan peningkatan taraf pendidikan yang sekaligus bermaksud untuk meningkatkan taraf hidup masyarakatnya. Hal ini diperkuat oleh (Fajar \& Mulyanti, 2019) yang mengatakan bahwa pendidikan merupakan hak seluruh rakyat Indonesia dan Negara bertanggung jawab untuk memberikan fasilitas sarana maupun pra sarana yang layak dalam pendidikan di Indonesia.

Indonesia merupakan Negara yang memiliki banyak pulau dari Sabang sampai Merauke. Salah satu daerah yang memiliki kekayaan sumber daya alam (SDA) berpotensial tinggi adalah Merauke yang berada di paling timur Papua. (Sugandi, 2008) mengatakan bahwa Papua menduduki posisi keempat tingkat tertinggi PRDB (Pendapatan Regional Domestik Bruto) dengan angka di atas 11 juta rupiah yang berkaitan dengan sumber daya alam (SDA). Namun, daerah tersebut seringkali dianggap terbelakang bagi mayoritas penduduk Indonesia karena sulitnya 
akses terhadap pelbagai kebutuhan pokok, antara lain pendidikan, kesehatan, dan ekonomi masyarakat.

Pendidikan di Merauke saat ini tergolong belum maksimal dikarenakan kurangnya produktivitas tenaga pengajar di daerah tersebut. "Tenaga pengajar yang ada di pedalaman rata-rata masih belum memenuhi kualitas S1. Idealnya, di Merauke harus memiliki 4016 guru, namun saat ini hanya ada 2000 guru", ungkap Sularso sebagai Wakil Bupati Merauke dalam rapat paripurna, Jumat, 4 Oktober 2019 (kabarpapua.com). Sementara itu, menurut data survei sosial ekonomi nasional tahun 2015 menunjukkan data bahwa penduduk usia 7-24 tahun sebanyak kurang lebih $70 \%$ masih bersekolah. Hal ini dapat diartikan bahwa, jumlah tenaga pengajar di Merauke tidak sebanding dengan pelajar yang mengemban pendidikan saat ini. Akibatnya, banyak tenaga pengajar yang berasal dari kota-kota besar turut berkontribusi dalam pendidikan di Merauke namun tidak dengan pembekalan yang matang sebagai tenaga pengajar. Selain itu, ada kondisi tertentu yang menyebabkan anak didik yang belum terbiasa untuk bersemangat dalam menuntut ilmu. Hal ini akan bermuara kepada tidak tercapainya tujuan Negara Indonesia untuk "Mencerdaskan Kehidupan Bangsa”.

Pendidikan tidak cukup jika hanya sebatas ilmu dan pengetahuan karena pendidikan semestinya diselaraskan dengan pembentukan karakter. Profesor Slamet Iman Santoso dalam buku yang ditulis oleh (Soedarsono, 2009) turut menegaskan bahwa tujuan dan sasaran utama pendidikan bukan semata-mata mengajar ilmu pengetahuan, melainkan melakukan tindakan nyata sesuai karakter yang dibentuk oleh pendidikan. Hal ini sejalan dengan Kementerian Pendidikan dan Budaya Republik Indonesia (Kemendikbud RI) yang menerapkan karakter sebagai poros pendidikan. Sejak tahun 2017 hingga saat ini, Kemendikbud RI sudah bergerak dalam penguatan pendidikan karakter (Cerdas Berkarakter) dan diharapkan agar tidak hanya diterapkan bagi masyarakat perkotaan, 
namun masyarakat di daerah seperti Merauke juga harus menerapkan pendidikan yang cerdas berkarakter.

Hasil penelitian terdahulu yang dilakukan oleh (Suparno, 2018) turut memperkuat bahwa pembentukan karakter para siswa dipengaruhi oleh faktor lingkungan sosial, lingkungan pendidikan, lingkungan budaya, pola asuh orang tua serta konsep diri. Oleh karena itu, saat ini para pelajar Merauke yang mengemban sebuah pendidikan pasti akan mengalami pembentukan budaya dan karakter dalam setiap individu yang sesuai dengan lingkungan sosial dan budaya di Merauke. Namun faktanya, terlihat bahwa pembentukan karakter yang terjadi di Merauke saat ini sedang dilanda dinamika problematika multidemensional, akibat adanya pengaruh budaya asing yang berkembang dan dapat berdampak pada pendidikan karakter, pertumbuhan ekonomi, serta ketahanan nasional. Dengan demikian, komunikasi yang aktif dan strategis sangat diperlukan sebagai elemen pendukung untuk menyelesaikan permasalahan-permasalahan nasional khususnya di Merauke.

Kementerian atau lembaga juga telah menyusun rencana strategis (renstra) sesuai dengan Rencana Pembangunan Jangka Menengah Nasional (RPJMN) yang memiliki tahapan pembangunan jangka panjang, jangka menengah, dan jangka pendek. Salah satu visi pembangunan nasional adalah untuk mewujudkan masyarakat Indonesia yang mandiri, maju, adil, dan makmur. Jika visi, misi, dan rencana-rencana pembangunan yang sudah dibuat oleh pemerintah tidak dikomunikasikan secara aktif dan masif, maka semua akan sia-sia dan tidak akan merubah kondisi nasional menjadi lebih baik lagi.

Pendidikan menjadi hal yang fundamental bagi pembangunan nasional berdasarkan pada pendidikan karakter. Hal ini dapat simak tampak bahwa permasalahan yang timbul di Merauke dalam bidang pendidikan dapat menjadi perhatian bersama untuk meningkatkan kondisi sosial ekonomi yang dapat berdampak besar pada kemajuan bangsa ini. Pemerintah dan para pengajar juga perlu mempelajari bagaimana strategi 
komunikasi dapat dijadikan sebagai jembatan untuk meningkatkan mutu pelayanan pendidikan di Merauke. Maka dari itu, penelitian ini bertujuan untuk mengetahui bagaimana kondisi dari implementasi kebijakan cerdas berkarakter yang telah dicanangkan oleh Kementrian Pendidikan agar dapat diterapkan secara merata di bagian timur Merauke melalui perspektif komunikasi. Lalu, penelitian ini juga ingin mengajak seluruh elemen lapisan masyarakat dan pemerintah untuk turut berpartisipasi dalam mewujudkan pembangunan pendidikan karakter yang berkualitas agar terciptanya kesejahteraan masyarakat yang makmur dengan menerapkan strategi komunikasi sebagai jembatan dari seluruh sistem sosial yang terbentuk di Merauke.

\section{METODE}

Metode penelitian menggunakan pendekatan deskriptif kualitatif. Melalui pendekatan kualitatif ini, peneliti berupaya mencari tahu dan menjelaskan secara induktif mengenai pendidikan karakter demi kesejahteraan taraf hidup di Merauke. Penelitian ini dilakukan dengan mengumpulkan data dan memecahkan rumusan masalah dari subjek penelitian dengan paradigma konstruktivis. Paradigma ini digunakan sebagai analisis sistematis terhadap socially meaningful action khususnya di wilayah Merauke melalui pengamatan langsung dan terperinci terhadap pelaku-pelaku sosial yang menerapkan karakter sebagai dasar dalam sebuah pendidikan demi menciptakan dan memelihara atau mengelola dunia sosial mereka.

Peneliti dijadikan sebagai alat penelitian itu sendiri karena berhubungan langsung dengan subjek yang akan diteliti dalam mengumpulkan data-data yang diperlukan. Sumber data dalam penelitian ini terdiri dari dua sumber yaitu sumber primer dan sumber sekunder. Sumber data primer dalam penelitian ini adalah narasumber yang berasal dari Merauke yang dapat dimintai keterangan seputar permasalahan yang dibahas dalam penelitian ini seperti para tokoh pemimpin agama, tenaga pengajar, para pelajar, Tentara Nasional Indonesia (TNI), dan masyarakat 
Merauke, sedangkan sumber data sekunder merupakan informasi yang diambil dari dokumentasi yang berkaitan dengan subjek penelitian. Data sekunder diambil melalui data Badan Pusat Statistik (BPS) Kabupaten Merauke, situs berita daring, dan kajian literatur lainnya yang relevan.

\section{HASIL}

\section{Gambaran Pendidikan di Merauke}

\subsection{Diagram Angka Partisipasi Murni (APM) Menurut Jenjang Pendidikan} dan Jenis Kelamin dan Partisipasi Sekolah di Kabupaten Merauke,

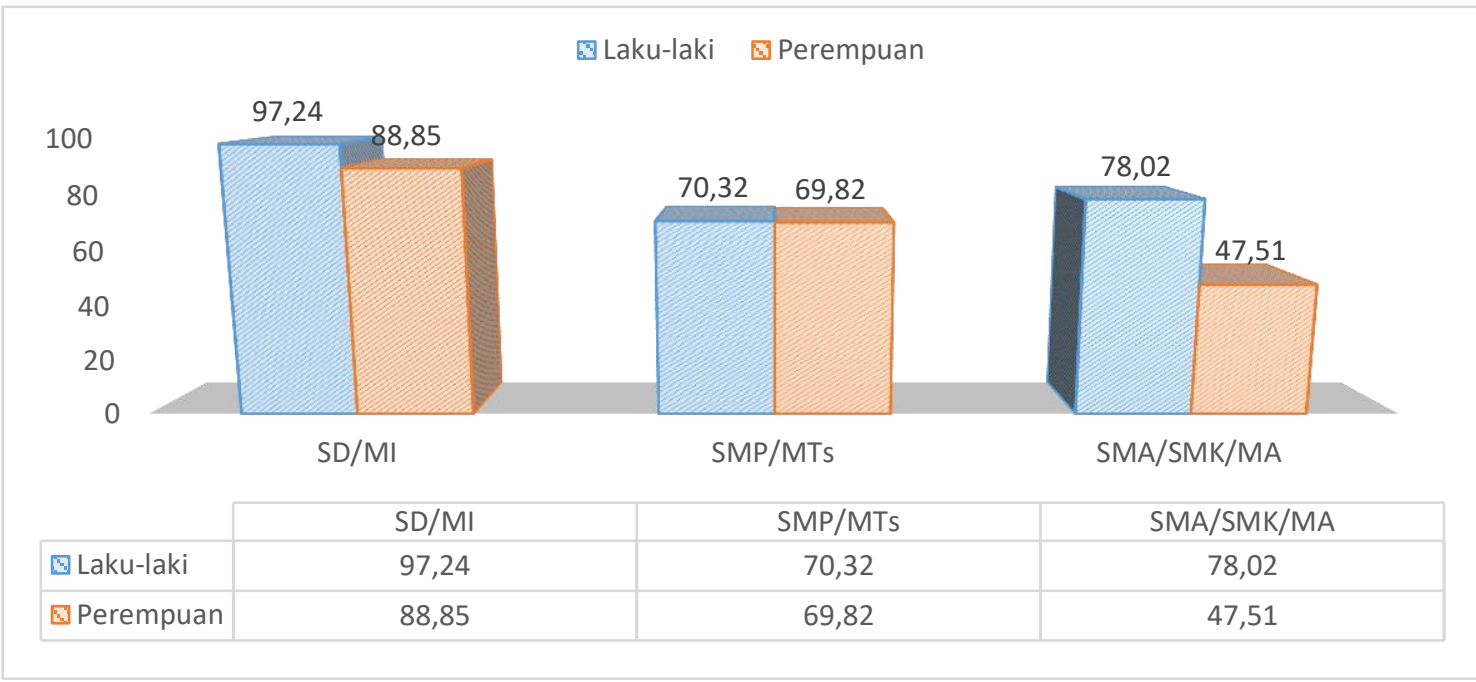

2018.

Sumber : Survei Sosial Ekonomi Nasional Kor, Maret 2015/National Socio Economic Survey kor, March 2015 yang dikutip dari Badan Pusat Statistik (BPS) Kabupaten Merauke dalam Angka 2019.

Pendidikan merupakan bagian dari aspek terpenting dalam pembangunan. Pada tahun 2017 ada sebanyak 81 Taman Kanak-kanak (TK), 204 Sekolah Dasar (SD), 59 Sekolah Menengah Pertama (SMP) dan 25 Sekolah Menengah Atas (SMA) serta 15 Sekolah Menengah Kejuruan (SMK) di Kabupaten Merauke sehingga secara keseluruhan ada sebanyak 384 fasilitas pendidikan di Kabupaten Merauke. Hingga saat ini, pemerintah provinsi Papua telah mengupayakan peningkatan partisipasi pendidikan ini sebagaimana diatur dalam Peraturan Daerah Provinsi Papua No 2 Tahun 2013 tentang Penyelenggaraan Pendidikan, diantaranya dengan menggratiskan biaya pendidikan bagi putra-putri asli 
Papua, memberikan beasiswa, hingga menekan biaya pendidikan bagi warga masyarakat Papua. Namun upaya ini masih belum maksimal karena melihat data Kementerian Pendidikan Nasional, Papua menduduki peringkat akhir dalam partisipasi sekolah.

Pendidikan dasar (SD-SMA) memiliki peranan yang penting dalam peningkatan sumber daya manusia (SDM) di masa yang akan datang. Hal ini disebabkan pendidikan dasar merupakan fondasi pada pendidikan selanjutnya, yakni pendidikan menengah hingga perguruan tinggi. Tujuan akhir dari pendidikan yaitu mencapai atau meraih lapangan kerja yang diinginkan untuk memenuhi kebutuhan sehari-hari. Selain itu, menurut (Setiawati, 2017), pendidikan merupakan hasil dari perkembangan kebudayaan manusia yang dibentuk melalui pembinaan karakter bangsa dalam rangka menjaga identitas bangsa dari kegoyahan arus globalisasi. Oleh sebab itu, pendidikan merupakan cara yang paling tepat secara akademis maupun karakter untuk menunjukkan kemampuan para pelajar di Merauke kepada seluruh masyarakat Indonesia bahkan masyarakat global karena pendidikan diyakini sebagai gambaran dari kemampuan, kecerdasan, sikap, dan tingkah laku dari seseorang.

Pendidikan memegang peran penting dalam upaya peningkatan kualitas sumber daya manusia (SDM) guna mempertahankan dan meningkatkan taraf kehidupan yang sejahtera. Faktanya, Angka Partisipasi Murni (APM) yang terlihat dari Data Badan Pusat Ststistik (BPS) Kabupaten Merauke belum mencapai angka yang memuaskan dari setiap jenjangnya. Sistem pendidikan nasional memiliki faktor-faktor penghambat dan keterbatasan dalam penerapannya, hal ini disesuaikan dengan ketetapan, kebijakan, bahkan situasi dan kondisi daerah masingmasing. Berikut faktor-faktor penghambat dalam penerapan pendidikan yang ada di Merauke:

a. Faktor kebijakan, yakni kurangnya ketegasan dari pemerintah pusat untuk menetapkan sebuah peraturan atau sebuah kebijakan yang 
berakibat tidak meratanya penyebaran tenaga pengajar di kota dan desa (kurangnya tenaga pengajar di desa).

b. Faktor pembangunan, yakni tidak meratanya pembangunan sarana dan pra sarana sekolah di Merauke.

c. Faktor lingkungan masyarakat, yakni kurangnya kesadaran diri sendiri dari masyarakat Merauke bahwa pentingnya pendidikan yang diimbangi karakter sebagai fondasi sejak dini.

\section{Gambaran Masyarakat dan Pendidikan Karakter di Merauke}

Masyarakat Merauke memiliki aktivitas sosial kemasyarakatan seperti daerah lain pada umumnya. Gambaran situasi dan kondisi masyarakat Merauke dapat dilihat secara khusus pada saat terselenggaranya kegiatan yang melibatkan Tentara Nasional Indonesia (TNI) bersama dengan Pelangi Indonesia Ministry. Kegiatan tersebut diselenggarakan secara serentak di seluruh penjuru Indonesia dengan berbagai macam kegiatan, antara lain penyuluhan narkoba ke sekolahsekolah, penyuluhan kesehatan dan kebersihan ke desa-desa, pengobatan gratis, doa lintas agama, dan kegiatan-kegiatan positif lainnya.

Kegiatan tersebut tentunya diadakan dalam rangka perwujudan nilai-nilai Pancasila bersama masyarakat Merauke yang tidak dibatasi oleh usia, gender, maupun golongan sekaligus untuk menginformasikan pentingnya pembinaan karakter khususnya dalam pendidikan dan memberi keyakinan kepada masyarakat bahwa pemerintah terus mengupayakan pengembangan pendidikan berbasis karakter di Merauke. Peneliti juga turut ikut berpartisipasi dalam kegiatan ini dan berhasil mengumpulkan data melalui observasi dan wawancara dengan berbagai stakeholders yang terkait dalam penelitian ini.

Tentara Nasional Indonesia (TNI), mengatakan bahwa: "Merauke merupakan daerah yang istimewa karena merupakan titik terujung dan paling timur di Indonesia yang berbatasan langsung dengan Papua 
Nugini". Masyarakat Merauke dapat hidup berdampingan, damai dan saling menghormati satu sama lain. Pertumbuhan ekonomi yang terjadi di Merauke bila dibandingkan dengan daerah lainnya di Indonesia masih sangat jauh tertinggal dan tergolong lambat. Upah Minimum Regional (UMR) Merauke saat ini sekitar Rp 3.516.700 (Keputusan Gubernur Papua No. 188.4/369/2019). Rata-rata mata pencaharian penduduk Merauke adalah sebagai nelayan karena penduduk Merauke sangat bergantung pada kekayaan laut Indonesia. Pendapatan seorang nelayan tergolong kecil dan berada di bawah Upah Minimum Regional (UMR) Merauke.

Menurut observasi lapangan secara langsung, peneliti melihat kondisi di kota Merauke sangat berbeda dengan kondisi yang berada di daerah pinggiran kota Merauke.Walaupun begitu, peneliti memperoleh hasil bahwa masyarakat Merauke masih memiliki antusiasme yang tinggi terhadap kegiatan positif yang diadakan oleh Tentara Nasional Indonesia (TNI) bersama dengan Pelangi Indonesia Ministry. Hal ini dapat dibuktikan ketika masyarakat Merauke khususnya para pelajar yang mengikuti rangkaian kegiatan yang positif ini dari awal hingga akhir. Kegiatan ini memiliki sasaran atau target utama yaitu kepada para pelajar yang masih bersekolah agar dapat menginternalisasikan karakter yang seharusnya ditunjukkan sebagai identitas anak bangsa. Sebagai anak bangsa, tentunya identitas merupakan hal pertama yang harus dijaga nama baiknya.

Menurut salah satu pelajar menengah atas di Merauke, memiliki identitas sebagai anak bangsa tidaklah mudah untuk dijalani oleh para pelajar di Merauke karena seiring berjalannya waktu akan terjadi perubahan dalam bidang sosial budaya. Perubahan ini yang akan berdampak pada cara pandang masyarakat maupun pemerintah di luar daerah Merauke (terbentuknya stereotype yang negatif). Hal ini dikarenakan oleh sebab, Merauke berbatasan secara langsung dengan negara tetangga yang menjadi garda depan bangsa. Lintas batas ini 
sering disalah gunakan dalam keluar masuknya budaya maupun perekonomian yang condong memiliki persoalan tersendiri jika tidak ditanamkan nilai-nilai kewaspadaan dan nasionalisme.

Salah seorang tokoh masyarakat menyampaikan fakta menarik mengenai situasi pendidikan di Merauke. Jika musim penghujan, besar kemungkinannya tenaga pengajar dan para pelajar untuk tidak hadir dalam proses ngajar mengajar di kelas. Maka, sudah dapat dipastikan proses belajar mengajar ditiadakan. Secara tidak langsung, hal ini akan berdampak pada terhambatnya pendidikan yang tidak berkembang sebagaimana mestinya karena kurangnya motivasi, kesadaran dan tanggung jawab dari masing masing tenaga pengajar dan para pelajar. Fenomena seperti ini, juga akan berdampak kepada menurunnya pendidikan sebagai tempat untuk membina dan mendidik generasi penerus bangsa yang berakhlak mulia sesuai dengan karakter yang sesuai dengan nilai-nilai Pancasila. Berikut beberapa indikator pendidikan karakter di Merauke:

Tabel 1 Indikator Pendidikan Karakter di Merauke

\begin{tabular}{clc}
\hline No. & \multicolumn{1}{c}{ Pendidikan Karakter } & Keterangan \\
\hline 1 & Komunikatif & Baik \\
2 & Mutual Understanding & Kurang \\
3 & Kreatif & Cukup \\
4 & Mewujudkan & Kurang \\
& (Inovatif) & \\
5 & Jujur & Sangat Baik \\
6 & Manajemen Resiko & Sangat Kurang \\
7 & Komitmen & Kurang \\
8 & Pengambilan Keputusan & Cukup \\
9 & Bertanggung Jawab & Kurang \\
10 & Disiplin & Sangat Kurang \\
11 & Beribadah & Sangat Baik \\
12 & Bersyukur & Baik \\
13 & Berpikir Kritis & Kurang \\
14 & Daya Saing & Sangat Kurang \\
15 & Rendah Hati & Kurang \\
16 & Mandiri & Kurang
\end{tabular}


17 Ulet

18 Tangguh

19 Toleransi

20 Kerjasama

21 Menghargai Perbedaan

22 Cinta Tanah Air

23 Semangat Kebangsaan

24 Peduli

25 Berani
Kurang

Cukup

Sangat Baik

Sangat Baik

Sangat Baik

Cukup

Baik

Sangat Baik

Cukup

Sumber : Wawancara dan observasi dari Informan (olahan data pribadi)

Karakter perlu dimiliki oleh setiap individu, termasuk masyarakat Merauke yang masih mengalami persoalan mengenai minimnya pendidikan karakter. Jika seluruh masyarakat Merauke sudah menerapkan prinsip pendidikan karakter, dapat pastikan akan mampu bertahan dari situasi dan kondisi yang sulit. Jika terjadi krisis, maka masyarakat Merauke akan mudah untuk bangkit dari keterpurukan yang melanda di daerahnya dan relatif cepat dalam memperbaiki krisis yang terjadi karena karakter akan berperan secara esensial sebagai daya juang untuk bangkit dari krisis yang sedang terjadi. Perpaduan antara pengaruh lingkungan yang merupakan internalisasi nilai-nilai ideologi dari luar dan aktualisasi nilai-nilai dari dalam diri dapat menghasilkan karakter yang kuat. Karakter yang kuat akan berdampak pada ketahanan nasional yang semakin kuat juga (Soedarsono, 2009).

Jurnal yang ditulis oleh (Setiawatri \& Kosasih, 2019) mengatakan bahwa kekuatan karakter yang dibentuk dalam lingkungan keluarga dan sekolah akan semakin baik jika ada dukungan dan dorongan dari lingkungan masyarakat sekitar. Selain itu, peneliti terdahulu (Napitupulu, 2006) juga mengungkapkan bahwa ada 3 (tiga) peran penting yang diyakini sebagai pusat dari pendidikan. Pertama, tenaga pengajar berperan sebagai tulang punggung dari sebuah proses pendidikan karakter seseorang karena kualitas para pelajar dapat ditentukan dari kualitas para pengajarnya. Kedua, keluarga berperan sebagai dasar pertama dari sebuah pendidikan yang berawal dari cinta kasih seorang 
orang tua untuk anaknya. Ketiga, masyarakat ikut berperan sebagai pembentukan sosial dari sebuah pendidikan. Ketiga pusat pendidikan ini hendaknya dapat bekerjasama dengan baik dalam mendidik generasi muda agar menjadi generasi penerus bangsa yang tangguh dan dapat diandalkan.

Permasalahan taraf hidup masyarakat Merauke seperti tidak berujung karena pembangunan karakter di Merauke masih terabaikan. Merauke saat ini sedang mengalami krisis multidemensi. Krisis multidemensi menurut (Marzuki, 2017) dapat dikatakan sebagai situasi yang dapat mengancam stabilitas bangsa, termasuk juga di dalamnya krisis yang menyangkut nilai-nilai moral yang dialami bangsa Indonesia yang masih terus berlangsung dan belum dapat diatasi. Akar persoalan dari timbulnya krisis multidemensi dikarenakan belum meratanya pendidikan dan adanya pengaruh paparan budaya asing di Merauke. Pemerosotan nilai-nilai moral saat ini terjadi di kalangan pelajar Merauke, hal ini dapat dibuktikan dari hasil wawancara dan observasi yang telah dilakukan. Kalangan pelajar di Merauke banyak yang terjerumus dengan pergaulan yang salah seperti mengkonsumsi obat-obatan terlarang. Informan mengatakan bahwa bukan hanya sesekali melainkan sering dijumpai anak-anak remaja di Merauke yang sedang menghisap lem aibon.

Hasil yang didapatkan dari informan (tokoh masyarakat dan tokoh agama) juga menjabarkan bahwa beberapa pelajar tidak disiplin dalam kegiatan belajar mengajar yang sedang berlangsung. Hal ini dikarenakan kurangnnya motivasi para pelajar di Merauke untuk belajar dan menimba ilmu, bahkan para pelajar lebih memilih untuk memancing ikan dibandingkan sekolah. Ada beberapa faktor yang menyebabkan para pelajar tidak mengikuti proses belajar mengajar dengan efektif karena kurangnya penerapan akan peraturan tata tertib sekolah, terdapatnya jam kosong yang tidak dimanfaatkan dengan kegiatan penunjang sekolah, kurang tegasnya tenaga pengajar dalam menegur siswanya, dan 
pembinaan moral para pelajar yang kurang efektif baik dalam lingkungan keluarga, masyarakat sekitar dan disekolah. Maka dari itu, diharapkan tenaga pengajar harus dapat berkomitmen untuk melayani para pelajar di Merauke dengan sepenuh hati guna menumbuhkan kesadaran dan motivasi para pelajar untuk menjadi anak bangsa yang cerdas berkarakter.

\section{PEMBAHASAN}

\section{Strategi Komunikasi Dalam Menangani Permasalahan Pendidikan Karakter di Merauke}

Permasalahan pendidikan karakter di Merauke dapat diselesaikan dalam perspektif komunikasi. Pembinaan karakter pada kalangan pelajar usia produktif membutuhkan strategi yang bersifat komunikatif yang efektif dalam penerapannya. Seperti yang dikemukakan oleh (Pace, Peterson, \& Burnett, 1997) bahwa strategi komunikasi memiliki empat tujuan untuk menentukan dan mengkomunikasikan bagaimana kebijakan cerdas berkarakter dapat dioptimalkan sebaik mungkin.

\section{(1) To Secure Understanding}

Salah satu informan yang merupakan bagian dari tenaga pengajar di Merauke, mengatakan bahwa seorang tenaga pengajar harus memiliki strategi yang kreatif dan inovatif dalam mengajar atau memberikan ilmu kepada para pelajar Merauke. Salah satunya tidak hanya belajar mengajar dikelas, akan tetapi bermain dipantai maupun diladang menjadi salah satu metode yang dapat diterapkan saat mengajarkan ilmu pengetahuan tentang alam. Berbeda halnya metode yang dilakukan oleh peneliti sendiri, peneliti mengenalkan wawasan nusantara dan kelndonesiaan kepada peserta didik dengan menggambar peta indonesia di pasir pantai sambil bermain. Metode informal semacam itu akan berdampak positif dalam pengembangan kreativitas yang mudah dingat oleh mereka. Hal ini di lakukan karena agar para pelajar di Merauke tidak mudah bosan dan 
terjadi miss understanding, sehingga nantinya akan berdampak pada terbentuknya pemahaman jangka panjang.

(2) To Establish Acceptance

Tenaga pengajar sudah sewajarnya memiliki sikap yang dapat mengayomi agar para pelajar di Merauke sadar jika mereka selalu diperhatikan dan dianggap keberadaannya. Maka dari itu, pengajaran yang telah diberikan perlu selalu dibina dan dipertahankan sebaik mungkin. Strategi komunikasi yang dapat diterapkan yaitu berkaitan dalam membina hubungan baik antara para pengajar dengan para pelajar di Merauke dengan saling memahami satu sama lain, karena setiap individu memiliki karakter dan wataknya masing-masing. Selain itu, para pengajar juga dapat menjadi sosok pendengar yang baik karena setiap orang pastinya selalu ingin didengarkan (baik berupa keluhan ataupun kebahagiaan). Sesekali juga tidak ada salahnya jika para pengajar memberikan apresiasi kepada para pelajar walaupun jika dipandang dari segi pemanfaatannya sangat kecil. Terakhir, selalu memiliki pemikiran terbuka (open minded) karena para pelajar pasti memiliki opini dan sudut pandang yang berbeda dalam cara berpikirnya.

(3) To Motivate Action

Temuan dalam penelitian ini tampak para pelajar di Merauke cenderung belum memiliki motivasi yang kuat dalam hasrat berprestasi di sekolahnya. Dengan demikian, diharapkan strategi komunikasi dapat memberikan motivasi dalam sebuah pengajaran yang dilakukan oleh para pengajar agar mampu memberi inspirasi dan dorongan untuk para pelajar agar memiliki hasrat berprestasi, hasrat untuk belajar, dan hasrat untuk berpikir kritis. Hal yang dapat dilakukan yaitu dengan menceritakan bagaimana pengalaman atau kisah saat menjadi siswa hingga saat ini menjadi pengajar namun tetap menyisipkan ilmu-ilmu pengetahuan yang baru setiap harinya. 
Selain itu, dalam meningkatkan motivasi para pelajar dibutuhkan pemahaman mengenai perilaku manusia. Perilaku merupakan respon atau reaksi seseorang terhadap lingkungannya yang berbentuk tindakan nyata atau tidak nyata (Sarwono, 2004). Menurut Skiner dalam buku Perspektif Perubahan Sosial (Saebani, 2016, hal. 133), ada dua jenis perilaku, yaitu perilaku tertutup dan perilaku terbuka. Perilaku tertutup merupakan respon atau reaksi terhadap stimulus masih terselubung atau belum dapat diamati secara jelas oleh orang lain, sedangkan perilaku terbuka merupakan respon atau reaksi terhadap stimulus yang sudah berbentuk tindakan nyata atau dapat diamati oleh orang lain.

(4) To Goals Which Communicator Sought To Achieve

Strategi komunikasi yang diterapkan memiliki tujuan agar para pelajar dapat dengan mudah memahami apa yang disampaikan oleh tenaga pengajar. Sayangnya, beberapa tenaga pengajar merasa strategi komunikasi dalam pengajaran hanya dianggap sebagai formalitas belaka dan menganggap bahwa pengajaran yang telah dilakukan sudah sesuai dengan apa yang seharusnya dilakukan. Padahal, pendidikan di daerah Merauke berbeda dengan kondisi di daerah Ibu Kota, tidak bisa disama ratakan. Kasus pada penelitian juga bersumber pada minimnya sosialisasi yang dilakukan sebagai pelatihan-pelatihan dalam mengembangkan strategi inovatif dalam metode pembelajaran di Merauke. Hal ini sejalan menurut (Dalimunthe, 2015) yang mengatakan bahwa untuk dapat mencapai pembelajaran karakter yang berkualitas perlu dirancang strategi yang inovatif.

Ke-empat tujuan strategi komunikasi tersebut sangat relevan dan sangat applicable untuk dijadikan panduan dalam mengatasi problema pendidikan karakter melalui perspektif komunikasi. Karakter yang secara garis besar belum dimiliki oleh para pelajar Merauke yaitu kedisiplinan, kesadaran atas diri sendiri, daya saing dan tanggung jawab. Hal ini bukan 
hanya tanggung jawab tenaga pengajar di sekolah saja, namun menjadi tanggung jawab bersama dari setiap individu yang berhubungan langsung dengan para pelajar. Baik itu dari pemerintah kepada para pelaku pendidik, maupun dari pendidik kepada peserta didik, ataupun peran orang tua dan masyarakat sekitar yang mendukung. Jika tujuan strategi komunikasi yang dilakukan oleh para tenaga pengajar dapat terpenuhi, maka pembentukan karakter dalam sebuah pendidikan dapat secara optimal diterapkan dalam kehidupan berbangsa dan bernegara guna meningkatkan kehidupan nasional yang sejahtera. Namun menurut (Arifin, 1984), dalam merumuskan strategi komunikasi terdapat 5 (lima) faktor yang harus diperhatikan, antara lain:

(1) Mengenal khalayak

Strategi komunikasi pertama yang menjadi dasar yaitu, perlu mengenal khalayak dengan cara mengetahui bagaimana budaya, karakter, dan kebiasaan pelajar di Merauke. Hal ini dilakukan sebagai langkah agar komunikasi interpersonal dan interaksi sosial dapat berjalan dalam atmosfer pendidikan di Merauke. Beberapa pengajar saat ini belum memiliki kesadaran bahwa pentingnya mengenal para pelajar Merauke. Informan mengatakan jika beberapa para pengajar pendatang masih enggan untuk mengenal lebih jauh para pelajar Merauke karena didasari pada kesenjangan status budaya.

(2) Menyusun pesan

Strategi komunikasi kedua yang perlu dilakukan oleh tenaga pengajar yaitu, perlu menyusun pesan pembelajaran secara rinci sebelum mulainya proses belajar mengajar berlangsung. Pesan pembelajaran yang disampaikan kepada para pelajar Merauke dapat dibuat dalam bentuk presentasi ataupun dalam tabel rancangan pembelajaran siswa (RPS). Sehingga pesan yang ingin disampaikan oleh para pengajar dapat terstruktur, terorganisir, dan tersampaikan dengan baik kepada para pelajar Merauke. 
(3) Menetapkan metode

Metode pembelajaran merupakan aspek yang harus diperhatikan dalam menyampaikan ilmu kepada para pelajar di Merauke karena di sinilah letak pesan pembelajaran harus dapat dikemas secara baik. Data yang diperoleh dari salah satu tenaga pengajar mengatakan bahwa setiap memberikan ilmu, tenaga pengajar selalu menggunakan alat permainan sebagai selingan guna menciptakan suasana pembelajaran yang seru, asik, dan menarik. Metode pembelajaran lain yang dapat dilakukan oleh tenaga pengajar yaitu dengan memberikan contoh kasus dalam setiap teori yang diajarkan agar setiap pelajar mampu mengerti bagaimana penerapan teori dalam praktiknya dalam kehidupan nyata, membentuk kelompok untuk membangun tanggung jawab, kerjasama dan kepedulian satu sama lain, memberikan kuis yang menyenangkan untuk menumbuhkan daya saing dalam setiap individu pelajar, membiarkan para pelajar untuk melakukan eksperimen-eksperimen yang menyenangkan dan selalu mengajak diskusi agar para pelajar merasa sadar bahwa keberadaannya berdampak bagi lingkungan sekitar, dan metode-metode lainnya. Jika metode pembelajaran yang dikemas sedemikian rupa sudah berjalan dengan efektif, tentunya motivasi pelajar dalam menimba ilmu sehari-hari juga akan meningkat pesat.

(4) Pemilihan penggunaan media

Strategi komunikasi erat kaitannya dengan penggunaan media sebagai alat penyampaian pesan. Tenaga pengajar diharapkan mampu untuk menggunakan media interaktif seperti menyiapkan bahan ajar dengan audiovisual yang ditampilkan pada proyektor untuk menunjang penyampaian informasi pembelajaran. Media interaktif tentunya mengacu pada layanan digital yang berbasis komputer dengan menyajikan pembelajaran melalui gambar bergerak (animasi), video, dan lain sebagainya. 
(5) Peranan komunikator.

Salah satu tenaga pengajar Sekolah dasar (SD) di Merauke mengatakan bahwa "para pelajar harus selalu diingatkan dan ditekankan secara terus menerus". Peran tenaga pengajar tentu menjadi harapan bagi para pelajar Merauke apalagi mengingat tenaga pengajar di Merauke mengalami krisis secara kuantitas. Tenaga pengajar memiliki posisi sebagai komunikator yang bersentuhan secara langsung dengan para pelajar (komunikan). Sebagai komunikator, sudah sepatutnya untuk menjadi penyampai pesan yang baik bagi para pelajar Merauke. Hal ini sejalan dengan peneliti terdahulu (Hendriana \& Jacobus, 2016) yang mengatakan bahwa pendidikan karakter di sekolah dapat diterapkan melalui keteladanan yang dilakukan guru dan juga dapat ditanam melalui pembiasaan secara terus menerus hingga karakter dalam pendidikan dapat tercermin dari apa yang dilakukan.

Para pengajar di Merauke rata-rata merupakan pendatang dari kotakota besar. Pembelajaran di kota-kota besar tidak dapat disama ratakan dengan pembelajaran di Merauke. Maka, kelima faktor tersebut harus dipahami dan diterapkan dengan sebaik mungkin agar kondisi pendidikan di Merauke tidak berlarut-larut menjadi sebuah keprihatinan nasional.

\section{Kapasitas Sumber Daya Manusia dan Implementasi Kebijakan “Cerdas Berkarakter” untuk Meningkatkan Taraf Hidup}

Undang-Undang Nomor 20 Tahun 2003 tentang Sistem Pendidikan Nasional Bab I Pasal 1 ayat 1 mengatakan bahwa pendidikan adalah usaha sadar dan terencana untuk mewujudkan suasana belajar dan proses pembelajaran agar peserta didik secara aktif mengembangkan potensi dirinya untuk memiliki kekuatan spiritual keagamaan, pengendalian diri, kepribadian, kecerdasan, akhlak mulia, serta keterampilan yang diperlukan dirinya, masyarakat, bangsa dan negara. 
Tujuan pendidikan nasional merupakan rumusan mengenai kualitas sumber daya manusia (SDM) yang harus dikembangkan oleh setiap satuan pendidikan di seluruh Indonesia khususnya dalam menerapkan pendidikan karakter saat ini. Hal ini sejalan dengan apa yang dikatakan oleh (Ismail, R dan Helmawati, 2018), pendidikan merupakan investasi sumber daya manusia (SDM) karena pendidikan merupakan proses pembelajaran yang menitikberatkan pada potensi manusia yang dimiliki untuk menyiapkan kapasitas sumber daya manusia (SDM) yang bermutu.

Manusia yang berkualitas dapat dijadikan sebagai dasar dalam pembangunan bangsa Indonesia. Hasil penelitian (Gaffar, 1987) menyebutkan bahwa bahwa faktor manusia bisa menjadi penentu bagi keberhasilan pembangunan suatu bangsa. Secara tidak langsung, manusia harus memiliki kemampuan untuk membangun potensi dalam diri (hardskill dan softskil) yang dapat dibina melalui pendidikan. Hal ini juga selaras dengan tujuan Pendidikan Nasional yaitu, mencerdaskan kehidupan bangsa sesuai dengan perkembangan IPTEK yang berlandaskan Pancasila dan UUD 1945. Sumber daya manusia (SDM) yang berkualitas juga diperlukan agar mampu menguasai dan mengembangkan ilmu pengetahuan dan teknologi.

Kapasitas sumber daya manusia juga dapat ditentukan dari proses interaksi sosial dalam kehidupan sehari-hari dan pengetahuan yang didapat, apalagi jika diiringi dengan pemahaman karakter nilai-nilai Pancasila sebagai anak bangsa. Nilai-nilai Pancasila yang dimaksud yaitu:

1. Memiliki prinsip secara religiusitas sesuai dengan masing-masing kepercayaan yang dianut. Hal ini diyakini sebagai wujud aktualisasi diri agar setiap individu dapat mencintai sang maha pencipta serta mengembangkan cara ber-keTuhanan yang penuh cinta kasih pula.

2. Memiliki prinsip kekeluargaan atau jiwa persaudaraan sebagai bentuk aktualisasi nilai-nilai etis kemanusiaan yang harus senantiasa mengakar kuat dalam kehidupan berbangsa dan bernegara. 
3. Indonesia adalah negara persatuan yang dikelola oleh konsep yang mengekspresikan persatuan dalam keberagaman dengan slogan "Bhinneka Tunggal Ika". Slogan ini diharapkan dapat menjadikan seluruh penduduk Indonesia untuk menjunjung semangat persaudaraan dengan persatuan dan kesatuan Republik Indonesia, sesuai dengan cita-cita bangsa Indonesia berbeda-beda tetapi tetap satu jua.

4. Memiliki prinsip musyawarah untuk mufakat dalam menetapkan setiap keputusan-keputusan mengenai persoalan bangsa. Hal ini harus menjunjung tinggi kedaulatan rakyat secara demokratis dalam setiap permusyawaratan. Keputusan yang diambil harus dipimpin oleh hikmat dan kebijaksanaan bukan dari golongan-golongan tertentu.

5. Sila kelima merupakan perwujudan nilai keadilan sosial yang mencerminkan imperatif etis dari sila pertama hingga sila keempat. Keadilan sosial selalu membicarakan mengenai keseimbangan, salah satunya mengenai keseimbangan dalam pemenuhan kehidupan sosial, ekonomi, dan budaya.

Nilai-nilai Pancasila di atas, diharapkan dapat diimplementasikan seiring dengan proses pembentukan karakter sebagai dasar dalam pendidikan di Merauke karena didukung oleh penelitian terdahulu (Asa, 2019) yang mengungkapkan bahwa implementasi dari pendidikan karakter di Indonesia harus bersumber pada Pancasila yang selama ini menjadi dasar penting. Jika memiliki karakter sebagai pondasi yang kuat, maka apa saja yang dikerjakan besar kemungkinannya akan berhasil karena memiliki softskill, terampil, ulet, gigih, berdaya juang tinggi, komitmen, bertanggungjawab, mandiri, dan karakter-karakter lainnya.

Manusia adalah makhluk sosial yang tidak dapat hidup sendiri, manusia pasti akan berkomunikasi dengan sesamanya untuk mengungkapkan apa yang diinginkan atau sekedar menyampaikan 
informasi. Proses komunikasi antar manusia dapat disebut proses interaksi sosial yang secara tidak langsung turut memberikan kontribusi dalam pembentukan pendidikan karakter. Proses interaksi sosial merupakan elemen terpenting yang berkaitan erat dalam aktivitas sosial pada masyarakat Merauke. Masyarakat yang terbiasa melakukan komunikasi dalam sosialnya akan berbanding lurus dengan aktivitas sosial yang dilakukan.

Implementasi kebijakan yang dilakukan oleh pemerintah pusat ataupun pemerintah daerah di Merauke saat ini masih belum mencapai hasil yang memuaskan karena kurang sinkronnya kebijakan pemerintah pusat dan kebijakan pemerintah di daerah Merauke dalam pemanfaatan kapasitas sumber daya manusianya (SDM) sehingga hal ini dapat berdampak kepada keputusan sepihak yang membuat kondisi pada daerah paling timur Indonesia tersebut menjadi marjinal. Van Meter dan Van Horn dalam buku menakar capaian otonomi khusus Papua (Katharina, 2019) mendefinisikan proses implementasi sebagai sejumlah tindakan oleh publik atau kelompok yang diarahkan untuk mencapai tujuan prioritas dalam sebuah keputusan kebijakan.

Merauke yang masih sering dipandang sebelah mata oleh berbagai golongan dan lapisan masyarakat Indonesia sudah harus dihapuskan. Terkadang media juga berperan sebagai aktor yang dapat mempengaruhi (seperti teori jarum suntik yang secara penuh dan sepihak dapat menyuntik pesan ke khalayak) sehingga Stereotype negatif lambat laun terbentuk oleh pemberitaan cerdas yang tidak propokatif terhadap masyarakat Indonesia. Padahal dalam kenyataannya, jika sumber daya alam (SDA) dan sumber daya manusia (SDM) di Merauke dapat dioptimalkan secara maksimal akan menjadi daerah yang sangat potensial untuk pembangunan secara lokal ataupun nasional. Sayangnya, saat ini implementasi kebijakan pemerintah pusat dan kebijakan otonomi daerah Merauke tergolong menjadi bias (tidak jelasnya tujuan perencanaan dan prioritas yang hendak dicapai dalam implementasi kebijakan di daerah 
Merauke) sehingga pemerintah daerah terkadang tidak memiliki wewenang penuh untuk mengelola, mengatur, ataupun mengeksplor sumber daya alam (SDA) dan sumber daya manusia (SDM) yang ada di Merauke.

Ditegaskan pula dalam Peraturan Pemerintah Republik Indonesia Nomor 17 Tahun 2010 Bab II Pasal 3 dengan jelas menyebutkan bahwa pengelolaan pendidikan bertujuan untuk menjamin akses, mutu pendidikan yang mencukupi, merata, terjangkau, efektif, efisien dan akuntabel. Namun faktanya, pengelolaan sistem pendidikan di Merauke yang masih terbatas dan masih belum adanya penegasan mengenai sanksi untuk para tenaga pengajar yang tidak komitmen serta tidak kompeten dalam mengajar. Selain itu, unsur kesadaran diri, kepekaan, dan daya tanggap juga diperlukan dalam sebuah implementasi kebijakan agar tujuan kebijakan di Merauke dapat tercapai. Jika kebijakan dari pemerintah tidak ada penegasan, kesadaran, kepekaan, dan daya tanggap maka akan terjadi multidemensi secara terus menerus yang dapat menggerus karakter dan moral bangsa Indonesia. Pemerintah pusat dan pemerintah daerah juga harus bersama-sama memikirkan jangka panjang dari program-program yang telah dibuat karena jika salah langkah, dampak yang ditimbulkan akan menjadi sumber permasalahan yang baru.

*Kerangka Berpikir dari Hasil dan Pembahasan Penelitian terlampir

\section{SIMPULAN (PENUTUP)}

Penerapan pendidikan karakter harus dimulai sejak dini agar generasi muda penerus bangsa dapat mempersiapkan kehidupan yang sejahtera di masa yang akan datang dengan menginternalisasikan nilainilai Pancasila. Dengan cara yang sangat sederhana sebagai contoh: Sila ke-1 KeTuhanan Yang Maha Esa, mampu mengajak dan meneladai untuk selalu bertaqwa atau taat kepada Tuhan dan menyayangi sesama manusia sebagai perwujudan kasih-Nya. 
Berdasarkan hasil dan pembahasan yang disajikan, menunjukan bahwa daerah Merauke masih mengalami krisis secara karakter dari kacamata pendidikan, seperti kedisiplinan, mandiri, berani, daya saing, mutual understanding, inovatif, bertanggung jawab, ulet atau tekun, berpikir kritis, komitmen, ulet dan tangguh, serta rendah hati. Maka dari itu, pembentukan karakter yang sejalan dengan ideologi Pancasila diperlukan untuk meminimalisir krisis multidemensional yang terjadi di Merauke dan bangsa ini.

Pembentukan karakter haruslah menjadi sebuah agenda utama atau keharusan bagi institusi pendidikan untuk menjadi prioritas kerja. Hal ini akan berdampak kepada peningkatan taraf hidup yang sejahtera, logikanya adalah jika mengamalkan sila Pancasila, masyarakat terampil, ulet dan tangguh, maka dapat dipastikan damai sejahtera. Kesadaran Orangtua juga berperan penting sebagai pengerak motivasi anaknya dalam mencapai pendidikan berkarakter, dengan cara senantiasa memberikan dukungan dan reward serta punishment yang seimbang.

Tenaga pengajar di Merauke juga mengalami kekurangan secara kuantitas karena perbandingan tenaga pengajar dan para pelajar yang kurang porposional sehingga berdampak pada proses kegiatan belajar mengajar. Terlepas dari itu, para pengajar di Merauke sudah semestinya dapat menjadi suri teladan bagi para pelajar di Merauke dengan menunjukkan aspek-aspek cerdas berkarter yang dicanangkan oleh Kemendikbud dan sudah sepatutnya untuk menerapkan pembelajaran melalui pendekatan komunikasi yang strategis agar dapat meraih tujuan pendidikan yang diinginkan bagi para pelajar Merauke.

Selain itu, pemerintah seyogianya memfasilitasi sekolah-sekolah di daerah pelosok sesuai sila ke-5 Pancasila yaitu Keadilan sosial bagi seluruh rakyat Indonesia. Kemudian diperlukan sikap tegas pemerintah terhadap pengajar di daerah pelosok dan perlu berupaya keras agar menetapkan program-program untuk membantu Merauke dalam mengejar ketertinggalannya dalam bidang pendidikan tidak hanya pendidikan 
formal, dapat berupa sosialisasi, penyuluhan, maupun pendidikan informal lainnya serta pelatihan bagi para pengajar yang dapat bermanfaat bagi perkembangan kondisi pendidikan di Merauke.

Sinergitas antar institusi dan seluruh elemen masyarakat dengan kolaborasi program yang sedang dijalankan dinilai belum optimal. Program pemerintah secara maksimal dapat diterapkan dengan menggandeng universitas dengan program tridarama perguruan tingginya, serta menggandeng yayasan yang konsen dibidang tersebut. Sinergitas program yang inline dengan cita-cita bangsa ini perlu mendapatkan dukungan penuh dengan mengesampingkan ego sektoral, demi mewujudkan kecerdasan bangsa.

\section{DAFTAR PUSTAKA}

[1]. Arifin, A. (1984). Strategi Komunikasi Sebuah Pengantar Ringkas. Bandung: AMRICO.

[2]. Asa, A. I. (2019). Pendidikan Karakter Menurut Ki Hadjar Dewantara Dan Driyarkara. Jurnal Pendidikan Karakter, Tahun IX, No. 2, 245258, from https://journal.uny.ac.id/index.php/jpka/article/view/25361/13037.

[3]. Dalimunthe, R. A. (2015). Strategi dan Implementasi Pelaksanaan Pendidikan Karakter di SMPN 9 Yogyakarta. Jurnal Pendidikan Karakter, Vol. V. No. 1, 102-111, from https://journal.uny.ac.id/index.php/jpka/article/view/8616/7108.

[4]. Fajar, C. M., \& Mulyanti, D. (2019). Meningkatkan Taraf Perekonomian dan Kesejahteraan Melalui Perencanaan Investasi Pendidikan. Jurnal Pengabdian Kepada Masyarakat, Vol. 2 No.1, 89-95, from https://ejournal.bsi.ac.id/ejurnal/index.php/abdimas/article/view/4971.

[5]. Gaffar, M. F. (1987). Perencanaan Pendidikan Teori dan Metodologi. Departemen Pendidikan dan Kebudayaan Direktorat Jendral Pendidikan Tinggi.

[6]. Hendriana, E. C., \& Jacobus, A. (2016). Implementasi Pendidikan Karakter di Sekolah Melalui Keterladanan dan Pembiasaan. Jurnal Pendidikan Dasar Indonesia, Vol. 1. No. 2, 25-29, from https://journal.stkipsingkawang.ac.id/index.php/JPDI/article/view/262/ 253. 
[7]. Ismail, R. (2018). Meningkatkan SDM Berkualitas Melalui Pendidikan, Menyiapkan SDM Papua yang Berdaya Saing. Bandung: Alfabeta.

[8]. Katharina, R. (2019). Menakar Capaian Otonomi Khusus Papua. Jakarta: Yayasan Pustaka Obor Indonesia.

[9]. Marzuki, H. (2017). Upaya Penumbuhan Kedisiplinan Peserta Didik Melalui Penanaman Nilai Karakter Di SD Negeri Montong Tanggak Kecamatan Kopang Kab. Lombok Tengah Tahun Pelajaran 2017/2018. Jurnal Pendidikan Mandala 28. Vol. 2 No. 2, hal. 28-45, from

http://ejournal.mandalanursa.org/index.php/JUPE/article/view/207.

[10]. Napitupulu, W. P. (2006). Mengapa Perlu Pendidik dan Tenaga Kependidikan untuk Pendidikan Luar Sekolah (Nonformal). Jurnal IImiah VISI-PNF Vol. 1 No. 2, 8-13.

[11]. Pace, R. W., Peterson, B. D., \& Burnett, M. D. (1997). Techniques for effective Communication. Addison-Wesley.

[12]. Saebani, B. (2016). Perspektif Perubahan Sosial. Bandung: Pustaka Setia.

[13]. Sarwono, S. W. (2004). Psikologi Remaja. Jakarta: CV Rajawali.

[14]. Setiawatri, N., \& Kosasih, A. (2019). Implementasi Pendidikan Karakter Peduli Sosial Pada Masyarakat Pluralis Di Cigugur Kuningan. Jurnal Pendidikan Karakter Tahun IX, No. 2, 179-192, from https://journal.uny.ac.id/index.php/jpka/article/view/22986.

[15]. Setiawati, N. A. (2017). Pendidikan Karakter Sebagai Pilar Pembentukan Karakter Bangsa. Prosiding Seminar Nasional Tahunan Fakultas IImu Sosial Universitas Negeri Medan, Vol 1, No. 1, hal. 348-352. Retrieved from https://pdfslide.net/documents/pendidikan-karakter-sebagai-pilarpembentukan-karakter-pendidikan-karakter.html

[16]. Soedarsono, S. (2009). Karakter Mengantar Bangsa dari Gelap Menuju Terang. Jakarta: PT. Alex Media Komputindo.

[17]. Sugandi, Y. (2008). analisis Konflik dan Rekomendasi Kebijakan Mengenai Papua. Jakarta: Friedrich Ebert Stiftung (FES).

[18]. Suparno. (2018). Analisis Faktor-Faktor Pembentuk Karakter Smart Siswa di Sekolah Islam Terpadu. Jurnal Pendidikan Karakter, Tahun 
VIII, No. $\quad 1, \quad 62-73, \quad$ from https://journal.uny.ac.id/index.php/jpka/article/view/21675.

\section{Sumber lainnya:}

[1]. Pancasila.

[2]. Undang-Undang Dasar 1945.

[3]. Undang-Undang Nomor 20 Tahun 2003 tentang Sistem Pendidikan Nasional Bab I Pasal 1 ayat (1).

[4]. Peraturan Pemerintah Republik Indonesia Nomor 17 Tahun 2010 Bab II Pasal 3.

[5]. Rencana Pembangunan Jangka Menengah Nasional (RPJMN).

[6]. Survei Sosial Ekonomi Nasional Kor, Maret 2015/National Socio Economic Survey kor, March 2015 yang dikutip dari Badan Pusat Statistik (BPS) Kabupaten Merauke dalam Angka 2019.

[7]. Modul Bidang Studi Sistem Manajemen Nasional (SISMENNAS) 2016. 


\section{Kerangka Berpikir dari Hasil dan Pembahasan Penelitian}

\section{NILAI-NILAI PANCASILA}

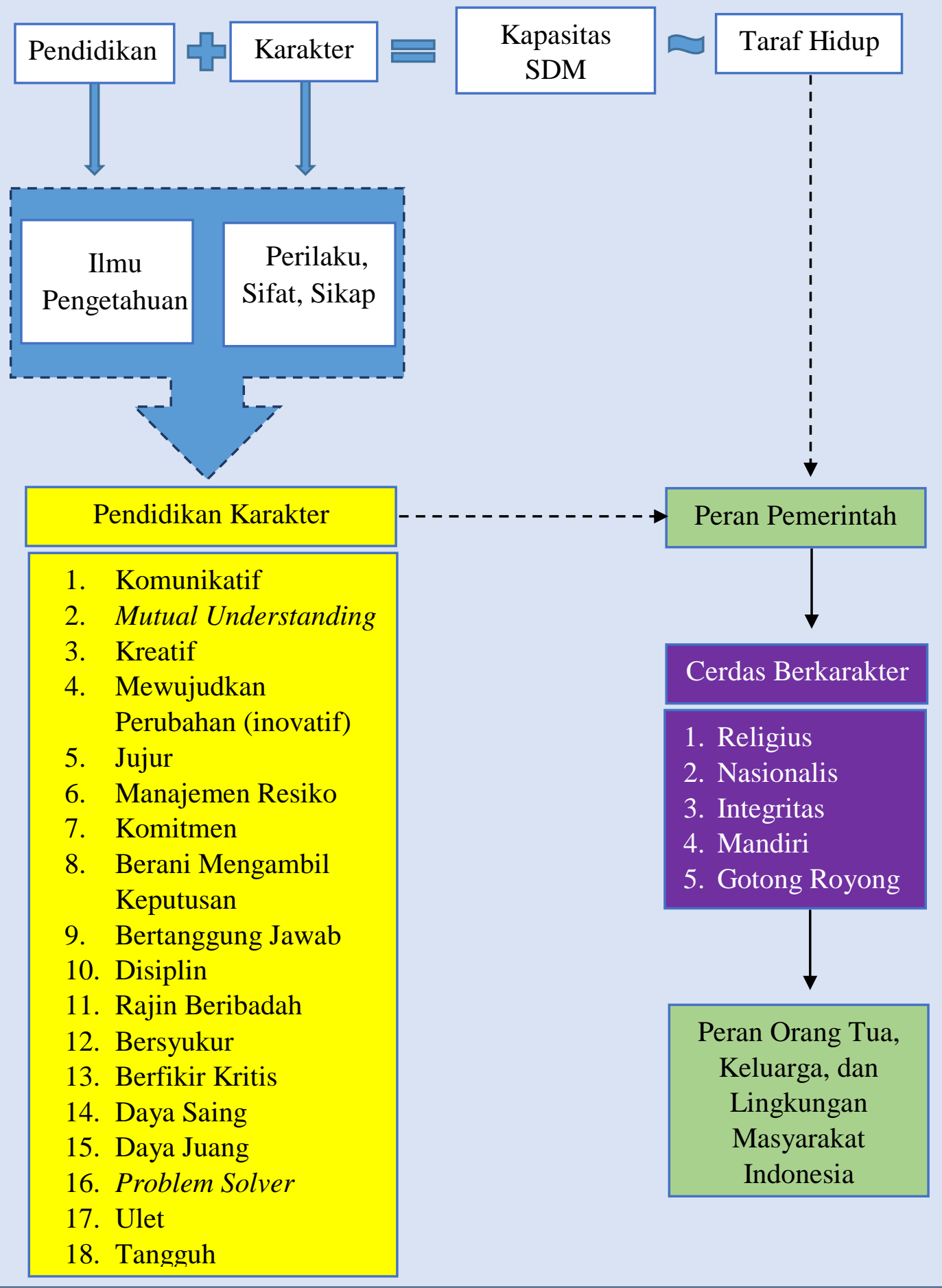

Sumber : Olahan Pribadi 